\title{
HOW THE UDMURT UNDERSTAND THE WORLD, AND MAN IN IT: BOOK REVIEW
}

Tat'yana Vladykina. 2018. The Udmurt Folklore 'Worldtext': Forms, Symbols, Rituals. Izhevsk

Tat'yana Vladykina is today certainly the most famous folklorist in Udmurtia. She is a Doctor of folkloristics, a leading researcher in the Udmurt research institute, ${ }^{1}$ and a professor at the Udmurt State University. She has written more than 300 publications about Udmurt folklore and traditional culture and has been editor of many books about folklore research. Her recent monograph The Udmurt Folklore 'Worldtext': Forms, Symbols, Rituals' (2018) sums up the results of a research process that has lasted decades. In this work, she systematises Udmurt representations of the world by analysing texts of different genres and screening calendar and kin rituals. Here lies the originality of this research. Only a scholar who has been familiar with Udmurt folklore for a very long time, and who has had the time and ability to synthesize her observations could write such a book. As Vladykina mentions, her sources are "different phenomena of language, of folklore, of religious cults, of decorative arts" (p. 35). The corpus of her sources covers a wide chronological spectrum, from the 19th to the beginning of the 21st century, published sources, archive materials, oral information from colleagues, and the author's own field research. The aim of this study is to analyse the Udmurt's traditional representations of the structure of the world, the understanding of space and time within calendar and kin rituals, and the place of man in the metaphorically constructed models of nature and society, all on the basis of lexical poetic metaphors and symbols, linguistic and cultural patterns, discursive clichés, terminological vocabulary, behavioural stereotypes, etc.

In her previous investigations Vladykina operated within a framework of precise genres, relying on the genre etic category to allow comparison between different cultures. Here she concentrates on the semantics of different topics, which she explores transversally. In the title of the monograph she uses the rare term worldtext, probably an invention, which reveals her wide semiotic understanding of what can be called text, a text that transmits the perception by the ethnic community and its understanding of the world. For the first time, Udmurt mythological representations are examined through the prism of the Udmurt mentality, which "along its historical and cultural evolution is submitted to change, acquiring new features and inevitably losing some" (p. 260).

The analysed historical and ethnographic material is presented in diachronic and synchronic cross-sections. The author includes within her interests historic data as well as contemporary material, revealing both evolution and stability. In some cases, she shows the changes undergone by some items, for example the new features acquired by the deity Nyulesmurt (forest man, forest spirit) (p. 101). In other cases, she highlights the stability of expressions, such as those used to describe eternity ("Shundy bertem, tolez' bertem, kizili bertem" 'the sun comes back, the moon comes back, the stars come back') (pp. 47-50), which have been recorded since the end of the 19th century to date.

The book is dedicated to the author's parents, both teachers, which undoubtedly influenced the insertion of the young Tat'yana into her village community. Three chapters are structured according to the logic of the Udmurt folklore worldtext, more generally according to the Udmurt under- 
standing of the world. Let us add that the content of all the three chapters is convincingly expressed in Vladimir Valer'yevich Nagovitsyn's illustrations at the opening of each.

In the first chapter, the author studies phenomena we are tempted to call supernatural, if this term, as always, was not so unsatisfactory. The cosmos is natural and so are gods and spirits as well as their representatives. Yet we are still tempted, because of the prefix 'super', which defines those phenomena through the point of view of man. The objects, subjects, phenomena of the other world are far away, high; they form the foundation and the conditions of the world inhabited by man; they surround it on all sides. Here, the author analyses mythological representations and topics relating to the creation of the world/light, the peculiarities and the hierarchy of heaven's luminaries, the roles of fauna representatives and natural items in the organisation of man's relations with gods and ancestors, with his environment. There is a very curious analysis of the importance of such characters, for example the bee and the goose/ swan in Udmurt traditional culture. As far as the significance of the bee is concerned, the author remarks that the bee and its particular role is present in almost all genres of Udmurt folk poetry. Vladykina also emphasises the highly symbolic and practical function of the goose in Udmurt mythical and ritual culture. She concludes that the goose in Udmurt culture is an envoy to the gods, informing them about a sacrifice or accompanying a sacrifice as a 'saviour' of the earth; the goose's character is perceived at the same level as the main celestial bodies, the Sun and the Moon. Not by chance is the Milk Way called in Udmurt the Way of the Wild Geese (Luddzh'azheg-Lobon-s'jures/ Luddzh'azheg-s'jures/Kyrzh'azheg-s'jures).

The second chapter examines the social organisation's mythological understanding within the perception of time and space. Relying on ritual ceremonies and on differ- ent folklore genres, we follow synchronic and diachronic cross-sections of the folk calendar, the landmarks of ethnic culture in time and space. The author had already developed these themes in one of her previous works (Vladykina and Glukhova 2011). The time and space worldview are analysed through such natural items as the source/ spring and the tree, the ritual and ordinary activities of village society, the socialisation of girls, as well as commemorative rituals. Describing the evolution of the Udmurt folk calendar, the author mentions that the modern calendar reflects an ethno-genetic processes in the Volga-Urals region that has taken many centuries and is an example of the mutual influence of cultures. For example, Vladykina clearly shows the local incorporation of the Orthodox Russian calendar in the Udmurt commemorative ritual system. The result of such processes is the organisation of communicative initiatives with the world beyond, which take place partly or entirely under the influence of the people's perceptions of time and space.

The last, third chapter has a very significant title, which is in clear opposition to Western anthropocentric approaches and 'puts man in his place': "In This World, We Are Guests". Guest is a modest but honoured place that implies duties and responsibilities. This chapter is dedicated to the behavioural stereotypes of the Udmurt in connection with the representations of life and fate and the place of man within the overall picture of creation. The author studies here sacral knowledge, which represents much more than ordinary knowledge, and which is connected with all kinds of human perception, including sensory. Here we must emphasise the importance and the interest of all the observations connected with language, with the use of language by the Udmurt, with the typical Finno-Ugric illocutivity. This dimension, we argue, opens fruitful perspectives that we may sum up with the expression 'word magic', to be understood in the widest meaning. Here 
there is a particularly interesting section, the one where the spiritual culture is studied on the basis of ethnic stereotypes, i.e. stereotypes of ethnic worldview, of ethnic awareness. It is the first time anecdotes circulating among the Udmurt have been used for analysis, and the finding is that they are deeply connected with ritual culture. Through contemporary Udmurt folklore, Vladykina draws a conclusion about the perception of the world by modern people: "separated from the ritual Purgatory of preChristian beliefs, not consciously, i.e.: spiritually led towards the Christian self-surpassing Purgatory, the Udmurt soul, originally non-aggressive, remains alone with the aggression of the world, and often turns this aggression towards himself" (p. 259).

This monograph generalises the author's previous work in this field. Her published studies introduce to scientific communication substantial and often new material and highlight deep layers of Udmurt folklore, religious traditions and ethnic psychology. The huge number of examples from different times just enrich the research, allowing the author to make her points fully and convincingly. We must emphasise the importance of contemporary testimonies as analysed sources, which enlightens the material and allows us to reflect on a living tradition. Another precious input of this book is the number of terms in Udmurt with their local variations. We would like to emphasise the deep philological sensitivity revealed by the author. Throughout the research we notice with interest the richness of her remarks on Udmurt words. She highlights both diachronically and synchronically the countless nuances and connotations of ordinary Udmurt words when they appear in the names of phenomena or rituals in order to expose their deepest nature. She makes a very justified remark, illustrated by many examples throughout the book: even culture bearers are not always able to interpret many concepts, so how much more difficult it is for scholars with mother tongues other than Udmurt (p. 235)! Clearly, she has great talent in illustrating the richness of the Udmurt language.

For some of the examples, she gives the local origin. We welcome this choice, and would even have liked it to be more systematic. It allows the author to specify the geography of the used data, and, while it is clearly not among the author's priorities she comments from the point of view of the whole ethnic group - this aspect is particularly interesting to the authors of this recension (and, possibly, not only us!).

The author uses traditional methods of scientifically analysing her material. She insists on participant observation, and particularly participant observation as a culture bearer herself, even if at the beginning she was not fully aware of the choice and its implications (p. 5). But by the time she writes this study, she fully understands its peculiarity and the privilege going with this position.

In the afterword, the author concludes that "traditional Udmurt culture selected the local and the dialectal sets needed for its identification, maintaining their archaic depth; only the period of globalisation has led them towards more abstract festival and stage forms" (p. 260).

Finally, Vladykina sets a task for the younger generation of researchers: to focus on an area that is almost unexplored in Udmurt traditional culture - the language of folklore. She reiterates the fact that scholars have started to build up the most necessary corpus of the Udmurt language and encourages them not to forget to include the challenges set by the language of the rich oral tradition. The conscious inclusion of the language of folklore could give the corpus additional richness and depth.

This book is an interesting reading for a wide circle of readers: folklorists, ethnologists, anthropologists, scholars of culture and those who are interest in folk culture, as well as simply people who are interested in the Udmurt and want to understand 
their worldview. Thus, this book is will be demanded by a wider readership than only scholars fascinated by Udmurt culture. Authors of recensions have expressed their satisfaction that this investigation has been published and are happy to wish the author the necessary inspiration, along with health and energy, to continue her exploration of the nature of folklore awareness.

Eva Toulouze (INALCO Paris France, University of Tartu), Nikolai Anisimov (Estonian Literary Museum, UIHLL Udm FRC UD RAS)

\section{Notes}

1 Udmurt Federal research centre of the Ural department of the Russian Academy of Science.

\section{References}

Vladykina, Tat'yana Grigor'yevna and Galina Anatol'yevna Glukhova. 2011. Ar-god-bergan: obryady $i$ prazdniki udmurtskogo kalendarya. Izhevsk: Udmurtskiy gosudarstvennyy universitet. [Владыкина, Татьяна Григорьевна и Галина Анатольевна Глухова. 2011. Ар-год-берган: обряды и праздники удмуртского календаря. Ижевск: Удмуртский государственный университет.]

Vladykina, Tat'yana Grigor'yevna. 2018. Udmurtskiy fol'klornyy mirotekst: obraz, simbol, ritual. Izhevsk: UFITS UrO RAN UIIYAL. [Владыкина, Татьяна Григорьевна. 2018. удмуртский фольклорный миротекст: образ, символ, ритуал. Ижевск: УФИЦ УрО РАН УИИЯЛ.] 